\title{
遺伝的アルゴリズムを用いたリアクティブスケジューリング*
}

（第 2 報, ジョブの追加に対する生産スケジュールの変更）

阪口龍彦*1, 谷 水義 隆*2, 杉 村 延広*2

\section{Genetic Algorithm Based Reactive Scheduling \\ (2nd Report, Modification of Production Schedule for Additional Jobs)}

\author{
Tatsuhiko SAKAGUCHI*3, Yoshitaka TANIMIZU and Nobuhiro SUGIMURA \\ ${ }^{* 3}$ Graduate School of Science and Technology, Kobe University, \\ 1-1 Rokkodai, Nada-ku, Kobe-shi, Hyogo, 657-8501 Japan
}

\begin{abstract}
A systematic scheduling method is required to modify the predetermined production schedules in order to cope with unforeseen changes in manufacturing systems. The objective of the present research is to propose a scheduling method based on GA (Genetic Algorithm) for modifying delayed production schedules due to the additional jobs, reactively. A prototype of reactive scheduling system is developed and applied to scheduling problems. The effectiveness of the proposed method is verified through the numerical expreriments of the reactive scheduling problems.
\end{abstract}

Key Words : Reactive Scheduling, Genetic Algorithm, Additional Jobs, Lower Bound, Variety

\section{1. 緒 言}

実際の生産活動では, 機械の故障やジョブの追加に より，あらかじめ作成した生産スケジュール通りに生 産活動を行うことが困難になる場合がある。このよう な生産システムの状況の変化に対応することができる 生産スケジューリング手法の一つとして, リアクティ ブスケジューリング(Reactive scheduling) $)^{(1)}$ がある.リ アクティブスケジューリングは, あらかじめ作成した 生産スケジュールに従って生産活動を行っている途中 に，予測していない変化が発生した場合，変化が発生 した時刻以降の生産スケジュールを変更するスケジュ ーリング手法である.

リアクティブスケジューリングの既存の研究(1)(2) で は, ルールを用いて生産スケジュールを変更する手法 が提案されている. しかし，どのような生産スケジュ 一ルでも適切に変更することができる優れたルールを 求めることは容易でない，そこで，第 1 報では，生産 活動中の作業に遅延が発生した場合に，遺伝的アルゴ リズム(Genetic Algorithm, 以下 GA と呼ぶ) ${ }^{(3)}$ を用いて 初期スケジュールを適切に変更するリアクティブスケ ジューリング手法を提案し，計算機実験により，その 有効性を検証した。本研究では, 生産活動中に製品才

* 原稿受付 2004 年 8 月 25 日.

*1 正員, 神戸大学大学院自然科学研究科( 657-8501 神戸市 灘区六甲台町 1-1).

*2 正員, 大阪府立大学大学院工学研究科( $599-8531$ 堺市学 園町 1-1)

E-mail : sakaguchi@ mech.kobe-u.ac.jp
一ダが追加された場合に, 初期スケジュールを迅速に 改善することができるようにリアクティブスケジュー リング手法を拡張する．次に，拡張した手法に基づき， リアクティブスケジューリングシステムのプロトタイ プを開発し，計算機実験を行うことで，本手法の有効 性を検証する。

\section{2. リアクティブスケジューリング}

$2 \cdot 1$ 用語と記号の定義 本論文中で使用する用 語と記号を以下に整理する.

- ジョブ (Job) : $J_{i}(i=1,2, \ldots, m)$

部品や組立品などの生産対象を表す.

- リソース (Resource) : $R_{j}(j=1,2, \ldots, n)$

ラインや工作機械などの生産資源を表す.

- オペレーション (Operation) : $O_{i, j}^{k, l}$

フライス加工やドリル加工など， ジョブ $J_{i}$ にリ ソース $R_{j}$ を用いて施す作業を表す. オペレーシ ョン $O_{i, j}^{k, l}$ は, ジョブ $J_{i}$ の工程順序の $k$ 番目のオペ レーションであり, リソース $R_{j}$ において $l$ 番目に 実行されることを表す．ただし， $k$ は工程設計に よりあらかじめ定められる順序であり，l はスケ ジューリングの結果から定まる順序である，才ぺ レーション $O_{i, j}^{k, l}$ は, 作業の開始時刻 $s t_{i, j}^{k . l}$, 終了時 刻 $f t_{i, j}^{k . l}$ および処理時閒 $p t_{i, j}^{k, l}$ の情報を持つ.

なお, リソースでは, 同時には一つの作業しか行え ないこととし, 一つのジョブは, 全てのリソースで 1 
回ずつ作業を施されるものとする。

スケジューリング問題は, 各リソースにおけるオペ レーションの適切な実行順序を決定する問題である.

本論文では, ジョプショップスケジューリング問題を 取り扱う. ジョブショップスケジューリング問題では, ジョブごとにオペレーションを施すリソースの順序が 異なる.

$2 \cdot 2$ リアクティブスケジューリング手法＼cjkstart第 1 報で提案した処理時間の遅延に対するリアクティブス ケジューリング手法 ${ }^{(4)}$ の概要を以下に示す.

リアクティブスケジューリングでは, 生産開始後に 生産スケジュールを変更するため, 既に開始したオぺ レーションおよびリアクティブスケジューリング中に 開始するオペレーションの実行順序, 開始時刻および 終了時刻を変更することはできない，そのため，それ 以外のオペレーションが, リアクティブスケジューリ ングの対象になる.

図 1 の例では, リソース $R_{1}$ におけるジョブ $J_{2}$ のオ ペレーション $O_{2,1}^{1.1}$ の遅延により, 総処理時間があらか じめ与えられた基準值 $C$ よりも大きくなったため, 時 刻 $T_{1}$ からリアクティブスケジューリングを開始する. 1 回のリアクティブスケジューリングプロセスに, $d t$ の計算時間を要すると考えると, $O_{2.1}^{1.1}, O_{3.2}^{1.1}, O_{4.2}^{1.2}$ お よび $O_{3.3}^{2.1}$ の 4 つのオペレーションは, その実行順序, 開始時刻および終了時刻を変更することができない. そのため, 残りのオペレーションに対して, リアクテ イブスケジューリングを行い, リソースにおけるジョ ブの実行順序, そのオペレーションの開始時刻および 終了時刻を変更する.

新たに求めた生産スケジュールの総処理時間が, 現 時点の総処理時間よりも小さい場合は, 新しい生産ス ケジュールに基づいて, 現時点の生産スケジュールを 更新する.さらに, 新たな生産スケジュールの総処理 時間が基準值 $C$ よりも大きい場合は, リアクティブス ケジューリングプロセスを繰返す.

第 1 報で提案した手法では，GA を用いてリアクテ イブスケジューリングを行う。まず，現状の生産スケ ジュールを表す個体を生成するためにコーディングを 行う.コーディングでは, 既に提案されている平野の 手法(5)を用いる。 すなわち, 図 2 に例示するように, 開始時刻の小さいオペレーションのジョブ名 $J_{i}$ を先頭 から 1 列に配置して個体を生成する. 次に, その順序 をランダムに入れ替えて, 複数個の個体を生成し, 初 期個体の集合を生成する. 生成した初期個体の集合に 対して遺伝的操作を行い, 次世代の個体の集合を生成 する. 生成した個体の集合に対して, 生産スケジュー
Initial production schedule (Predetermined)

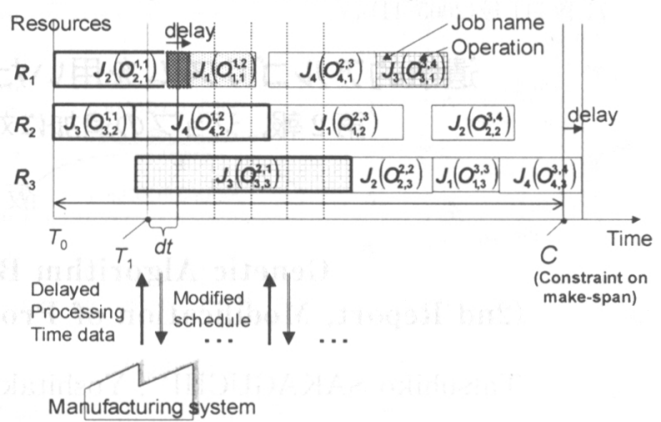

Fig. 1 Reactive scheduling process

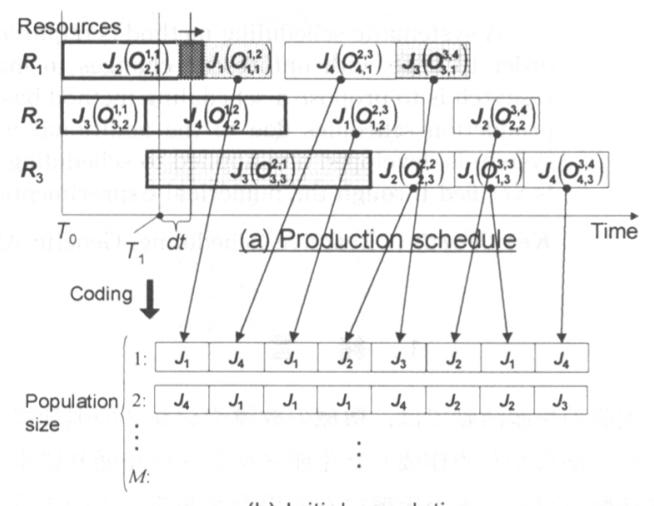

(b) Initial population

Fig. 2 Creation of initial population

ルを作成するためにデコーディングを行う。これによ り，個体の先頭に配置されているジョブから順番にリ ソースヘオペレーションを割り当てる. その際, 既に 実行順序が決まっている他のオペレーションを調べ, 最も早い時刻に当該のオペレーションを開始できる時 刻を探索し，それを開始時刻とする. この時，当該の オペレーションに先行するオペレーションが終了して いること，およびオペレーション間に当該のオペレー ションを挿入することができる空き時間があることが 必要になる(5).

本手法では, コーディング, 遺伝的操作, デコーデ イングの一連の操作を 1 回行う処理を, 1 回のリアク ティブスケジューリングプロセスとする. 1 回の操作 で生産スケジュールが改善された場合, 現行の生産ス ケジュールと入れ替える。これを繰返しながら, リア クティブスケジューリングプロセス間で個体を継承す ることにより, 生産スケジュールを段階的に改善する ことができる.

$2 \cdot 3$ ジョブの追加に対する処理 ここでは, 新 しいジョブ $J_{x}$ が追加された場合に，リアクティブスケ 
ジューリングシステムが解くべき問題を述べる。

まず， 前節に示すリアクティブスケジューリング手 法において，初期個体の生成時に，追加すべきジョブ のオペレーションを含む個体を生成し, 遺伝的操作を 行うことで新しい生産スケジュールを作成する必要が ある.その際，適切な生産スケジュールの解を短時間 で求めるためには，適切な初期個体を生成することが 重要である.

一般に，GA では個体の集合が多様であり，かつ適 切な評価基準值を持つことで，適切な解を早期に求め ることができると言われている(6)，そのため，本論文 では，初期個体の生成時に解空間内において広く分散 し，かつ評価基準(総処理時間)の観点から適切な初期 個体を生成することを考える。ここでは, 準最適な初 期スケジュールに，追加すべきジョブを適切に挿入す ることで，多様かつ適切な初期個体の集合を生成する 方法を提案する。すなわち，追加すべきジョブ $J_{x}$ の才 ペレーションを $O_{x, j}^{y, \bullet}(j, y=1,2, \ldots, n)$ とするとき, リソー ス $R_{j}$ において, 追加すべきジョブの $y$ 番目のオペレー ション $O_{x, j}^{y, \bullet}$ を初期スケジュールの適切な位置(以下, 時間区間と呼ぶ)に挿入して，初期個体の集合を生成 する手法を提案する。ここで，・は未決定変数を表す、

\section{3.ジョブの追加に対するリアクティブ スケジューリング手法}

$3 \cdot 1$ 適切な初期個体の生成 ここでは, 適切な 初期個体を生成するために，新しいジョブを追加する 時間区間について検討する。

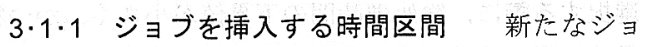
ブのオペレーションを挿入することができる時間区間 は、リソースごとに複数個存在する。しかし，各時間 区閒の大きさが異なるため, オペレーションの追加が 総処理時間に与える影響は同じではない.そこで，本 研究では，全余裕時閒と遊休時間を足した值が大きい 時閒区閒を選択し，新たなジョブのオペレーションを 挿入することで，生産スケジュール全体の総処理時間 の増加量の小さい初期個体を生成する方法を提案する. 図 3 に示すように, 初期スケジュールにおいて, リソ 一ス $R_{j}$ における $p$ 番目のオペレーション $O_{0 . j}^{\circ, p}$ の最早完 了時刻を eft $t_{\bullet . j}^{\bullet p}$, リソース $R_{j}$ における $p+1$ 番目のオぺ レーション $O_{0 . j}^{\cdot p+1}$ の最遅開始時刻を $l s t_{0 . j}^{\cdot p+1}$ とすると, 全余裕時閒と遊休時間を足した時間区間の大きさ $v t_{j . p+1}$ は，式(1)で表すことができる.

$$
v t_{j, p+1}=l s t_{\bullet . j}^{0, p+1}-e f t_{\bullet . j}^{\bullet \cdot p}
$$

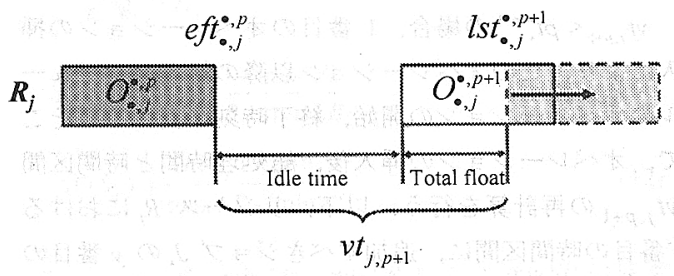

Fig. 3 Vacant time slot

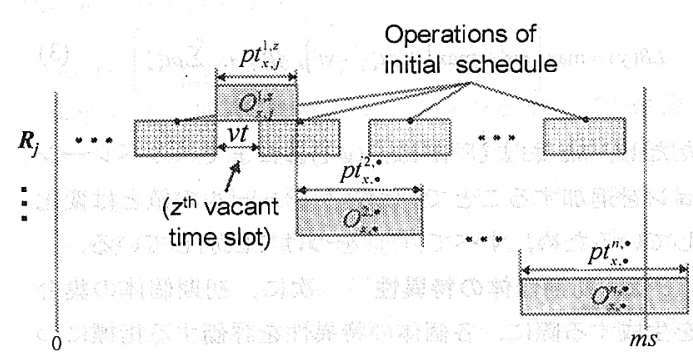

Fig. 4 Lower bound value of increase in make-span

この時閒区閒に挿入するオペレーションの処理時間を $p t_{\cdot . j}^{\cdot p+1}$ とすると, $v t_{j, p+1}>p t_{0 . j}^{\circ, p+1}$ の場合, 生産スケジュ 一ル全体の総処理時閒は増大しない。また， $v t_{j, p+1}<p t_{0 . j}^{\circ p+1}$ の場合, 総処理時間は $p t_{. . j}^{\circ p+1}-v t_{i, p+1} た ゙ け$ 増大する。これは，追加すべきジョブ $J_{x}$ の全てのオぺ レーションを挿入し終わるまで初期スケジュールのジ ヨブの処理順序は変更しないため, 処理時間 $p t_{0 . j}^{\circ p+1}$ の オペレーションを $v t_{j, p+1}$ の位置に挿入すると，このオ ペレーションがスケジュールにおけるクリティカルパ ス上に存在することにより明らかである.

$3 \cdot 1 \cdot 2$ 総処理時間の下界值 図 4 に示すように, 初期スケジュールの総処理時間を $m s$ として, リソー ス $R_{j}$ における $z$ 番目の時間区間に, ジョブ $J_{x}$ の 1 番目 のオペレーション $O_{x, j}^{1, z}$ を挿入する場合を考える.この とき, $\mathrm{z}$ 番目の時間区間の全余裕時間と遊休時間を足 した大きさを $v t$ とすると，総処理時間の下界值は以下 のようになる.

$$
L B(1)=\max \left[m s+\max \left[0, p t_{x, j}^{1, z}-v t\right], f t_{x, j}^{1, z}+\sum_{a=2}^{n} p t_{x, \bullet}^{a, 0}\right]
$$

ここで, $\max \left[0, p t_{x, j}^{1, z}-v t\right]$ は新たにオペレーションを 追加することによる総処理時間の増加量を表す。また， $f t_{x, j}^{1, z}+\sum_{a=2}^{n} p t_{x, \bullet}^{a, \bullet}$ は, 追加したオペレーションの終了時刻 に残りオペレーション $O_{x, \bullet}^{a, \bullet}$ の処理時間の総和を足した 值であり，追加したジョブの処理が最も早く終了する 時刻を表す。 


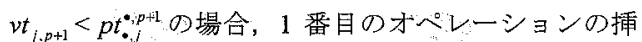
入により,このオペレーション以降の初期スケジュー ルのオペレーションの開始，終了時刻が変わる，そこ で，オペレーションの挿入後，“総処理時間上時間区間 $v t_{j, p+1}$ の再計算を行う，以下，リッース $R_{j}$ における $z$ 番目の時間区間に, 追加ずへきジョブ $J_{x}$ の $y$ 番目の オペレーション $O_{x ; j,}^{y, z^{\prime}}$ を追加する場合も，同様に次式 で総処理時間の下界值を求めることができる.

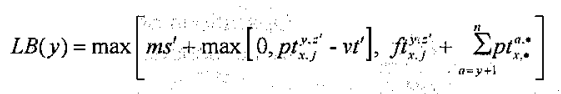

ただし， $m s$ および $v t$ 惊，(y-1)番目までのオペレーシ ヨンを追加听ることで初期スケジュールの值とは変化 しているため，すべて「」をつけ別している。

3.2 初期個体の特異性 次に，初期個体の集合 を生成する際に，各個体の特異性を評価する指標にっ

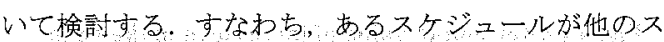
ケジュールに対してどれだけ異なるかを示す指標を考 える.

ショブの数が $m$ ，リソースの数が $n$ のジョブショッ プスクジューリング閣題において， $S_{p}, S_{q}$ といら 2 つ の生産スケジュールの相違 $\operatorname{dif}\left(S_{p}, S_{q}\right)$ は, Brizuela 5 の 研究(7)によって式(4)のように定義されている.

$$
\begin{aligned}
& \operatorname{dif}\left(S_{p}, S_{q}\right)=\sum_{a=1 b=1}^{n} \sum_{p q} \partial_{p}(a, b)
\end{aligned}
$$

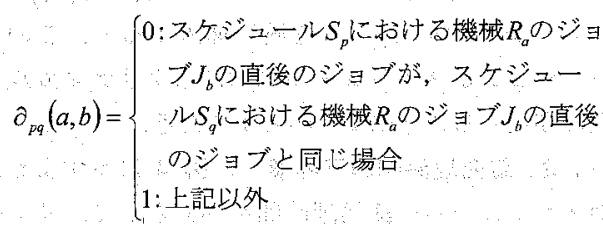

式(4)は，一対の生産スケジュールの差異を定量的に評 価する指標である。いま，追加すべきジョブが $n$ 個の オペレーション者持っており,これらのオペレーショ ンを $n$ 個のリソースの適当な時間区間以洀入すること で, $\gamma$ 個のスタジュール群 $\left\{S_{d}\right\}(d=1,2, \ldots, \gamma)$ を生成し たと考える。このとき， $n$ 個のオペレーションはす心゙ て異なるリソースで実行される，そのため，スケジュ 一ル群 $\left\{S_{d}\right\}$ から任意の一対のスケジュール $S_{p}$ と $S_{q}$ を取 り出し，その相違を式(4)で評価すると，dif( $\left.S_{p}, S_{q}\right)$ は以 下の範囲になる。

$$
2 \leq \operatorname{dif}\left(S_{p}, S_{q}\right) \leq 2 n \quad(p \neq q)
$$

これは，それぞれのリソースに一つずつオペレーショ シを追加することから明らかである。このとき $\gamma$ 個の スケジュール群 $\left\{S_{d}\right\}$ にお忛る一つのスケジュール $S_{p}$ の

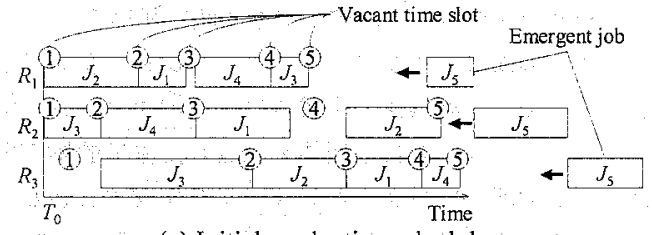

(a) Initial production schedule

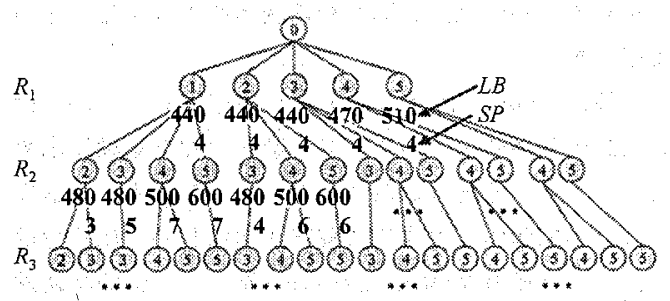

(b) Search tree

Fig. 5 Example of beam search

特異性 $S P\left(S_{p}\right)$ を次式で定義する。

$$
\begin{aligned}
& S P\left(S_{p}\right)=\sum_{q=1}^{\gamma} \delta_{p q} \quad(p \neq q) \\
& \delta_{p q}=\left\{\begin{array}{l}
0: \text { if } \operatorname{dif}\left(S_{p}, S_{q}\right)=2 n \\
1: \text { if } \operatorname{dif}\left(S_{p}, S_{q}\right)<2 n
\end{array}\right.
\end{aligned}
$$

上式は， $S_{p}$ 之の差異が $2 n$ 末満のスケジュールの数を スケジュール群 $\left\{S_{d}\right\} の$ 中から数え上げるものであり， 数值が小さいほどスケジュールの特異性が高いことを 表す、そこで，オペレーションを挿入する時間区間を 選択する際に，総処理時間の下界值が小さく，かつ特 異性の高い時間区間を選択することにより，適切かっ 多様な初期個体の集合を生成する。

3.3 リアクティブスケジューリングプロセス ジョブ $J_{x}$ が追加された場合，以下の手順でリアクティ ブスケジューリングを行う。

Step1：リアクティブスケジューリングの対象となる オペレーションの選定

現在時刻を $T_{x}, 1$ 回のリアクティブスケジューリン グプロセスに要する計算時間を $d t$ とすると，開始時刻 $s t_{i, j}^{k i}$ が以下の条件を満たすオペレーション $O_{i, j}^{k . l}$ は，リ アクティブスケジューリングの対象となる.

$$
s t_{i, j}^{k, l} \geq\left(T_{x}+d t\right)
$$

式(7)を満たすオペレーションが存在しない場合は，り アタティブスケジューリングプロセスを終了する. 
Step2 : 初期個体の集合 $P_{1}$ の生成

リアクティブスケジューリングプロセスの繰返しに おいて, 1 回目すなわち時刻 $T_{1}$ でのリアクティブスケ ジューリングプロセスと, 2 回目以降すなわち時刻 $T_{2}$ 以降のリアクティブスケジューリングプロセスでは, 初期の個体集合 $P_{1}\left(T_{x}\right)$ を生成する方法が異なる.

Step2-1: $T_{x}=T_{1}$ の場合

ジョブ $J_{x}$ の全てのオペレーション $O_{x, j}^{y, \bullet}(j, y=1,2, \ldots, n)$ に対して, 以下に示す処理を繰り返すことにより, 初 期個体の集合 $P_{1}\left(T_{1}\right)$ を生成する.

Step2-1-1：新しいオペレーションの挿入

リソース $R_{j}$ の $z$ 番目の時間区間に, ジョブ $J_{x}$ の $y$ 番 目のオペレーション $O_{x, j}^{y, z}$ を挿入する. 図 $5(\mathrm{a})$ に示す例 の場合, $y=1$ の時, 抙入するための時間区間の候補が, リソース $R_{1}$ において 5 個ある.これを, 図 5(b)に示す ような探索木のノードで表す. また， $y>1$ の場合, ジ $\exists フ ゙ J_{x}$ の $y$ 番目のオペレーション $O_{x, j}^{y, z}$ の開始時刻 $s t_{x, j}^{y, z}$ と, $y-1$ 番目のオペレーション $O_{x, \bullet}^{y-1, \bullet}$ の終了時 刻 $f t_{x, \bullet}^{y-1, \bullet}$ の間では, オペレーションの工程順序の制約 から, 次式を満足する必要がある.

$$
f t_{x, \bullet}^{y-1, \bullet} \leq s t_{x, j}^{y, z}
$$

よって, リソース $R_{j}$ の $z$ 番目の時間区間 $v t_{j . z}$ の終点 $f$ と, ジョブ $J_{x}$ の $y-1$ 番目のオペレーション $O_{x .0}^{v-1 \cdot \bullet}$ の終 了時刻 $f t{ }_{x . \bullet}^{v-1 ・ \bullet}$ に次式の関係が成り立つ場合は, その時 間区間にはジョブ $J_{x}$ の $y$ 番目のオペレーション $O_{x, j}^{y, z}$ 挿入することができない.

$$
f \leq f t_{x \cdot \bullet}^{v-1 .}
$$

よって，図 5(b)に示すように, 式(9)を満たさないノー ドは，以降の探索の候補から削除する.

Step2-1-2: 総処理時間の下界值と特異性の評価

Step2-1-1 で生成した各ノードに対して, 総処理時間 の下界值 $L B(y)$ と生産スケジュールの特異性 $S P\left(S_{p}\right)$ を 求める. 図 5(b)の各ノードの数值は, 下界值 $L B(y)$ と 特異性 $S P\left(S_{p}\right)$ の值を表す. 次に，各ノードの下界值と 特異性の線形和を評価値 $E V$ として次式で定義する.

$$
E V=\alpha \cdot N L B(y)+(1-\alpha) \cdot N S P\left(S_{p}\right)
$$

$0 \leq \alpha \leq 1$

ここで，NLB(y)および $N S P\left(S_{p}\right)$ は, 式(2), 式(3)および 式(6)で示した $L B(y), S P\left(S_{p}\right)$ を正規化した值で, 次式
により計算する.

$$
\begin{aligned}
& N L B(y)=\frac{L B(y)-\min L B}{\max L B-\min L B} \\
& N S P\left(S_{p}\right)=\frac{S P\left(S_{p}\right)-\min S P}{\max S P-\min S P}
\end{aligned}
$$

ここで, $\max L B, \min L B, \max S P$ および $\operatorname{mix} S P$ は探索 木の同じレベルのノードにおける $L B$ および $S P$ の最大 値および最小值を示す.

Step2-1-3 : 探索を継続するノードの選択

Step2-1-1 で挿入したオペレーションがジョブの最後 のオペレーションである場合は探索を終了し， Step21-4 に進んで初期個体を生成する.そうでない場合は,

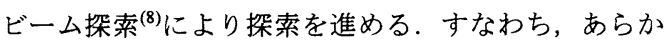
じめ設定したビーム幅 $w$ 個分のノードを， Step2-1-2 で計算した評価值 $E V$ の小さいノードから順に選択す る. 次に, 選択したノードに対し，yを一つ増加し Step2-1-1 から繰り返す. 図 5(a)の初期スケジュールに 対して, ジョブ $J_{x}$ の 3 つのオペレーションを挿入する 時間区間の候補を表す探索木を図 5(b)に示す.

Step2-1-4 : 初期個体の生成

探索木の最下位のノードのうち, 評価值 $E V$ の小さ いノードから順に集団サイズ $M$ 個分のノードを選択 し，各レベルのノードを決定する．これらのノードの 情報をもとに，ジョブ $J_{x}$ のオペレーションを各リソー スの時間区間に挿入し， $M$ 個の生産スケジュールを作 成する.このスケジュールにおいて，開始時刻の小さ いオペレーションからそのジョブ名を 1 列に並べて, 初期個体の集合を生成する.

\section{Step2-2: $T_{x} \geqq T_{2}$ の場合}

時刻 $T_{2}$ 以降では, 第 1 報で提案したように, 時刻 $T_{x-1}$ のリアクティブスケジューリングプロセスの Step3 で求めた次世代の個体の集合 $P_{2}\left(T_{x-1}\right)$ を利用して, 時 刻 $T_{x}$ の初期個体の集合 $P_{1}\left(T_{x}\right)$ を生成する.

Step3 : 次世代の個体の集合 $P_{2}$ の生成

Step2 で生成した初期個体の集合 $P_{1}\left(T_{x}\right)$ に対して遺伝 的操作を行い, 次世代の個体の集合 $P_{2}\left(T_{x}\right)$ の個体を $M$ 個生成する.ここでは, 遺伝的操作として, ルーレッ 卜選択，2点交叉，および逆位を用いる.

Step4 : 生産スケジュールの更新

Step3 で生成した個体に対してデコーディングを行 い, $M$ 個の生産スケジュールを作成する. 作成した生 産スケジュールの総処理時間 $m s_{r}(r=1,2, \ldots, M)$ を計算し, 
その最小值が現行のスケジュールの総処理時間より小 さい場合，最小值を持つ生産スケジュールを現行の生 産スケジュールと入れ替える。

Step5 : 終了判定

総処理時間が，あらかじめ決められた基準值 $C$ より も小さい場合は，全ての処理を終了する，そうでない 場合は, Step1から繰返す。

\section{4. 計算機実験}

本研究では，ジョブの追加に対して，第 1 報で開発 したリアクティブスケジューリングシステムのプロト タイプを拡張した．次にこのシステムを用いて計算 機実験を行った。実験の対象として，ジョブ数 50, リ ソース数 10 のジョブショップ型生産システムを用い た．なお，各オペレーションの処理時間は Storer， $\mathrm{Wu}$, Vaccari のジョブショップスケジューリングのための ベンチマーク問題(9)のうち, swv11 という問題を使用 した．また，追加するジョブの工程順序はランダムに 設定し，処理時間は 1〜200(sec)でランダムに決定した。

まず，GA を用いたスケジューリングを行い準最適 な初期スケジュールを作成した，GA のパラメータは， 予備的実験により, 個体数 $M=50$, 交叉率 0.5 , 突然変 異率 0.1 とした. 次に, 工程順序および処理時間をラ ンダムに設定したジョブを，生産活動の開始から 66 秒後に追加した．それにともない，スケジュールの総 処理時間が増大し，基準値を超えたため，開発したプ ロトタイプシステムは自動的にリアクティブスケジュ
ーリングを開始した. 重み $\alpha=0.5$, ビーム幅 $w=50$ と し，10例の試行を行った．その結果を図 6 に示す. 図 の横軸は生産活動を開始した時点からの経過時間を，

縦軸は各時点においてリアクティブスケジューリング の結果得られた生産スケジュールの総処理時間を表す。 ジョブの追加で増加した総処理時間は，リアクティブ スケジューリングの進行にともない徐々に改善したこ とがわかる. 一方, 新たなジョブのオペレーションを 初期スケジュールの最後尾に追加した後，前報のリア クティブスケジューリング手法を用いてスケジュール を改善した結果を図 6 に示す. 本研究で提案した手法 は，初期個体を生成するために約 120 秒の計算時間を 要したが，従来の手法を用いて生成したスケジュール よりも総処理時間の小さいスケジュールを迅速に得る ことができた.

次に， $a$ を〜 の間で変化させ，各重みについて 10 回ずつリアクティブスケジューリングを実行した. その結果を図 7 に示す. 図の横軸は重み $\alpha$ を, 縦軸は リアクティブスケジューリング終了時の総処理時間の 最大值, 最小値および平均值を示した。これにより， $\alpha=0.6$ の場合が最も総処理時間の短い生産スケジュー ルになることがわかる，すなわち，下界值および特異 性の両方を考慮することにより，迅速に適切な生産ス ケジュールを求めることができる.

さらに，新たなジョブのオペレーションをランダム に挿入することにより初期個体を生成する方法との比 較を行った．なお，提案手法の重みは $\alpha=0.6$ とする.

実験では，工程順序および処理時間をランダムに設定

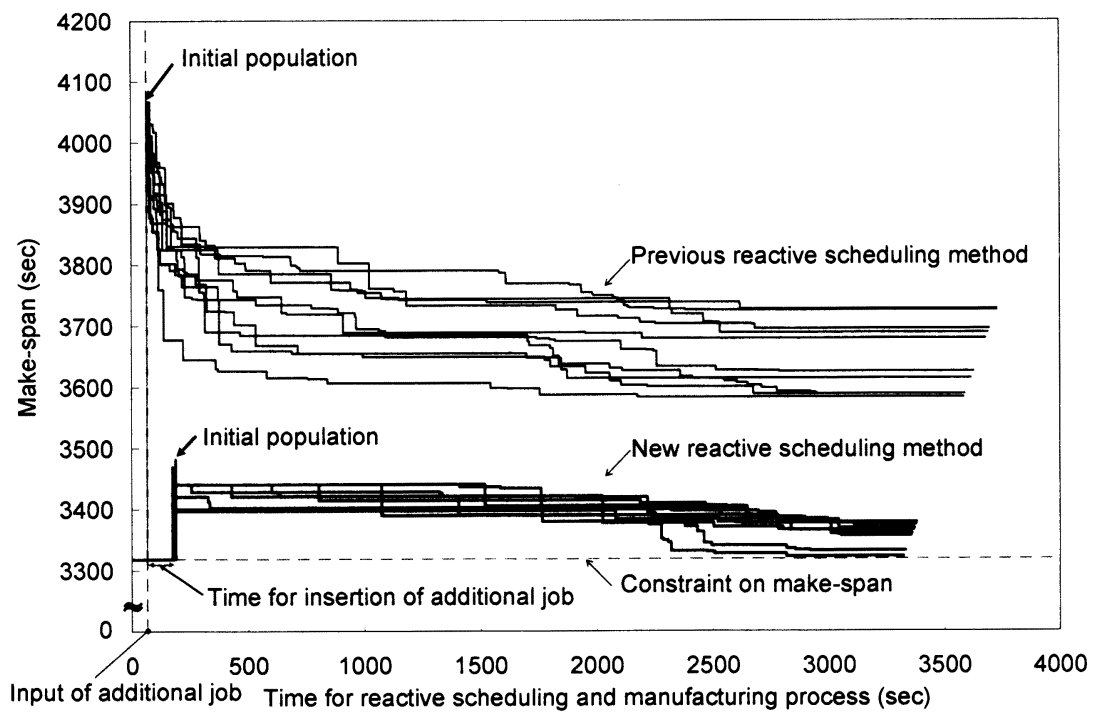

Fig. 6 Experimental result of reactive scheduling 


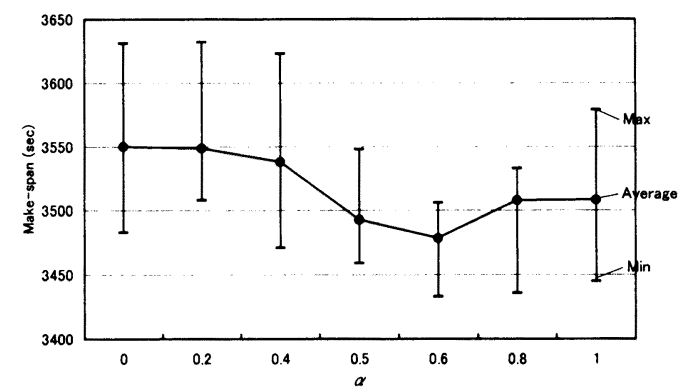

Fig. 7 Experimental results for different weight

Table 1 Comparison between two methods

\begin{tabular}{|c||c|c|c|}
\hline \multicolumn{1}{|c||}{} & \multicolumn{3}{c|}{ Make-span [Average] (sec) } \\
\cline { 2 - 4 } & $\begin{array}{c}\text { After input } \\
\text { of } 1^{\text {st }} \text { job }\end{array}$ & $\begin{array}{c}\text { After input } \\
\text { of } 2^{\text {nd }} \text { job }\end{array}$ & $\begin{array}{c}\text { End of } \\
\text { reactive } \\
\text { scheduling }\end{array}$ \\
\hline \hline $\begin{array}{c}\text { Randomly } \\
\text { inserted }\end{array}$ & 3649.6 & 3744.4 & 3533.2 \\
\hline $\begin{array}{c}\text { Proposed } \\
\text { method } \\
(\boldsymbol{\alpha}=\mathbf{0 . 6})\end{array}$ & $\mathbf{3 4 8 0 . 7}$ & $\mathbf{3 5 7 3 . 2}$ & $\mathbf{3 4 7 8 . 5}$ \\
\hline
\end{tabular}

Table 2 Comparison with real-time scheduling

\begin{tabular}{|c|c|}
\hline Scheduling method & Make-span (sec.) \\
\hline FCFS (First Come First Service) & 4366 \\
\hline LPT (Largest Processing Time) & 5031 \\
\hline SPT (Shortest Processing Time) & 4265 \\
\hline Proposed method (Average) & $\mathbf{3 4 7 8 . 5}$ \\
\hline
\end{tabular}

した 2 種類のジョブを連続して投入した．表 1 は，各 ジョブの挿入直後の生産スケジュールの総処理時間の 平均值, およびリアクティブスケジューリング終了時 の生産スケジュールの総処理時間の平均值を示した.

これにより, 提案手法は, ジョブが連続して投入され る場合においても適切なスケジュールを迅速に求める ことができると考える.

さらに, ディスパッチングルールを用いて生産スケ ジュールを決定する手法(10)-(12) との比較を行った．実 験結果の比較を表 1 に示す. GA は, 確率的な操作を 伴うため, 提案した手法は 10 回の試行の平均値を示 す.これにより，简便なディスパッチングルールを用 いた手法より, 提案手法の方が, 総処理時間の小さい 生産スケジュールを作成することができた.

\section{5. 結言}

本研究では, 新しいジョブの追加に対応することが できるリアクティブスケジューリング手法を提案した. この手法は, 第 1 報で提案した手法を拡張したもので
ある.その内容をまとめると以下のようになる.

(1) 新たなジョブの追加により増加する総処理時間の 下界值およびスケジュールの特異性に基づいて, 適切かつ多様な初期個体を生成することで, 生産 スケジュールを迅速に改善する手法を提案した.

（2）計算機実験により，下界值と特異性を考慮して初 期個体を生成することで，適切な生産スケジュー ルを求めることができることを検証した，さらに， 複数のジョブを連続して投入した場合における本 手法の有効性を示した.

\section{文 献}

(1) Smith, S. F., Intelligent Scheduling Systems, (1995), 155-192, Kluwer Academic.

(2) 西岡靖之, 計測と制御, 33-7(1994), 571-574.

(3) Holland, J. H., Adaptation in natural and artificial systems, (1975), University of Michigan Press.

(4) 谷水義隆・阪口龍彦・杉村延広, 機論, 69-685, C (2003)，234-239.

(5) 平野広美, 応用事例でわかる遺伝的アルゴリズム プログラミング, (1995), パーソナルメディア.

(6) 西川禕一・玉置久, 計測自動制御学会論文集, 29-5(1993), 589-595.

(7) Brizuela, C. A. and Sannomiya, N., GECCO 1999, (1999), 75-82.

（8）圓川隆夫・伊藤謙治, 生産マネジメントの手法, (1996), 102-103, 朝倉書店.

(9) Storer, R. H., Wu, S. D. and Vaccari, R., Management science, 38(1992), 1495-1509.

(10) Shin, H., Kuroda, M., Advances in production management systems, (1996), 399-410, Chapman \& Hall.

(11) Hatono, I., et al, Advances in production management systems, (1996), 423-434, Chapman \& Hall.

(12) Sugimura, N., Tanimizu, Y., Ae, S., Proc. of APMS'99, (1999), 466-473. 